\title{
Construction Product Quality Improvement with Applying Production Problems Analysis
}

Renata Stasiak-Betlejewska

Faculty of Management. Czestochowa University of Technology. Armii Krajowej 19B, 42200 Częstochowa. Poland. Email: renatastasiak@wp.pl

The study and analysis of the production process of the aluminum joinery allow identyfing factors significantly affecting the product quality. The main factor is undoubtedly the experience of employees, skills and the knowledge acquired during training and the aluminium ironworks. To improve construction aluminium product quality, production areas with identified nonconformities are the object of the analysis. Detection of nonconformities is an important element in this type of post-operative control process. It is recommended mainly to control the cutting sections, folding and crimping. The reliability increase performed on these operation positions significantly affects the product quality. The modernity level of the machinery has also significant meaning mainly for the process productivity.

Keywords: Alluminium Joinery, Quality, Production Control, Value Engineering

\section{Acknowledgement}

This work is related to the scientific program of the "Improving quality of processes, products and services" BW 615/201/07 supported by Polish Ministry of Science and Higher Education.

\section{References}

[1] BORKOWSKI, S., STASIAK-BETLEJEWSKA, R. (2010). Analysis of anti-corrosion coating process on steel constructions. In Manufacturing Technology. Vol. 10, No. 10, pp. 27 - 29. ISSN 1213-2489

[2] MICHNA, Š., LUKÁČ, I., OČENÁŠEK, V., KOŘENÝ, R., DRÁPALA, J., SCHNEIDER, H., IŠKUFOVÁ and coll. (2005). Encyklopedie hliníku. Adin, Prešov, ISBN 80-89041-88-4.

[3] MICHNA, Š., NOVÁ, I. (2008). Technologie a zpracování kovových material. Adin, s.r.o.,Prešov, ISBN 978-8089244-38-6.

[4] VAJSOVÁ, V., NÁPRSTKOVÁ, N. (2009). Structural Inhogomenity by Al-Cu Alloys Casting into Metal and Bentonic Form. In ,10th International Scientific Conference Automation in Production Planning and Manufacturing, Turčianské Teplice, SR. ISBN 978-80-554-0008-2.

[5] VAJSOVÁ, V., NÁPRTKOVÁ, N. (2009). The Homogenization Anealing of AlCu4MgMn Alloys. In Borkowski S. Selejdak, J. Toyotarity. Realization of production/services processes., Dnipropetrovsk.

[6] GARRATT, A. (1967). Value Engineering. Management Decision, Vol. 1 Issue 3 pp. 49 - 54.

[7] GREEN, S. (1990). The essentials of value engineering. Facilities. Vol. 8 Issue: 10 pp. 15 - 17

[8] MICHNA, Š., LUKÁČ, I., NÁPRSTKOVÁ, N. (2009). Optimalizace mechanických vlastností u slitiny AlSi12CuMgNi. In Strojírenská technologie. Vol. 14, No. 2. pp. 9-14, ISSN 1211-4162.

[9] ANNAPA, C. M., PANDITRAO, K. S. (2012). Improving Furniture Product thorugh Value Engineering by Function Analysis Systems Technique (F.A.S.T.). International Journal of Application or Innovation in Engineering\&Management Vol. Issue 4: pp. 5 - 11.

[10]KUŚMIERCZAK, S., NAPRSTKOVA, N., SVOBODOVA, J. (2012). Evaluation of sheet degradation with surface treatment. 11th International Scientific Conference on Engineering for Rural Development Location: Latvia Univ Agr, Fac Engn, Jelgava, LATVIA, MAY 24-25, 2012.pp. 32-36

[11]LEGUTKO, S., KROLCZYK, G., KROLCZYK, J. (2014) Quality Evaluation of Surface Layer in Highly Accurate Manufacturing. In Manufacturing Technology. Vol. 14, No. 1, pp. 50-56, ISSN 1213-2489

[12]NOVÁ, I., MACHUTA, J. (2014) Monitoring of the Structure and Quality of Aluminium Castings in Moulds of Gypsum Mixtures. In Manufacturing Technology. Vol. 14, No. 3, pp. 381-387, ISSN 1213-2489

[13]DIAN, M. (2013), The Methodology of Quality Matrix in Manufacturing Quality Process Improvement, In Manufacturing Technology. Vol. 13, No. 4, pp. 431-437, ISSN 1213-2489

[14]STASIAK-BETLEJEWSKA, R. (2012). Value engineering as the way of quality problems solving in the steel construction management. In Manufacturing Technology. Vol. 12, No. 13, pp. 431-437, ISSN 1213-2489 